\title{
ФОРМУВАННЯ МЕТАКОГНІЦІЙ МАЙБУТНІХ ФАХІВЦІВ У ВИЩІЙ ШКОЛІ: ДОСВІД ТА ПЕРСПЕКТИВИ ВПРОВАДЖЕННЯ У НАВЧАЛЬНИЙ ПРОЦЕС ВІТЧИЗНЯНИХ НАВЧАЛЬНИХ ЗАКЛАДІВ
}

У статті актуалізовано проблему удосконалення підготовки майбутніх фахівців з урахуванням когнітивно-стильових особливостей навчальної пізнавальної діяльності. Ключовим психологопедагогічним механізмом підвищення ефективності оволодіння професійними знаннями визначено метакогнітивні прочеси. Узагальнено теоретичні висновки щодо змістових характеристик метакогніцій. Доведено необхідність врахування механізмів дї метакогнітивних проиесів у професійній підготовичі майбутніх фахівців. Окреслено перспективи розробки та впровадження авторських програм метакогнітивного навчання у вітчизняних ВНЗ.

Ключові слова: вищча школа, професійна підготовка майбутніх фахівців, когнітивні процеси, метакогнітивні процеси.

Постановка проблеми. У контексті розбудови вітчизняної вищої школи на засадах євроінтеграційних процесів у галузі освіти все частіше у педагогічній науці й освітній практиці акцентують увагу на формуванні у майбутніх фахівців особливих інтегруючих, надпредметних властивостей [1:350-352]. Ученими підкреслюється, що саме вони дають змогу студенту контролювати та регулювати власну розумову діяльність і, таким чином, забезпечують не тільки академічну успішність, але й орієнтують у площині вирішення полісистемних особистісних та професійних завдань - площині наскрізного саморозвитку.

Аналіз результатів багаторічних світових досліджень, які спрямувались на визначення універсальних компетенцій конкурентоспроможних фахівців у наступних десятиріччях, узагальнений у межах проекту "Рейтинг ВНЗ України "Компас - 2012", ініційованого компанією "Систем Кепитал Менеджмент" висновками "Випускники українських ВНЗ очима роботодавців" [2], підтверджує значущість здатності майбутнього фахівця до учіння впродовж життя, умінь працювати в умовах невизначеності, керувати власним мисленням, пам'яттю, увагою, уявою тощо. Саме ці характеристики і забезпечуються особливим пізнавальним процесом, який американський учений Дж. Флейвелл уперше назвав метапізнанням (метакогніцією) - чітко визначеною спрямованістю на усвідомлення особистістю механізмів управління власною розумовою діяльністю [3: 127-179].

В узагальненому контексті досліджень зарубіжних та вітчизняних науковців (А. Браун, Г. Еверсон, М. Келлер, Р. Клюве, М. Рейд, С. Тобіас, Дж. Флейвелл, В. О. Волошина, Т. І. Доцевич, А. В. Карпов, С. Д. Максименко, І. Д. Пасічник, І. М. Скітяєва та ін.) когнітивний стиль (когніції) визначає стабільну індивідуальну характеристику способів взаємодії людини 3 інформаційним простором, стійкість процесуальних особливостей пізнавальної діяльності, а метакогніцітивні процеси активно досліджуються як важлива умова підвищення успішності пізнавальної діяльності.

Незважаючи на значний досвід вивчення метакогніцій у різних сферах наукового знання, наявність апробованих програм метакогнітивного навчання у зарубіжних ВНЗ, проблема цілеспрямованого розвитку метакогнітивних знань та вмінь у майбутніх фахівців у просторі вітчизняної вищої освіти залишається актуальною, що і зумовлює пошук шляхів підвищення освітніх послуг з урахуванням дії метакогнітивних процесів.

Отже, мета статті і полягає у визначенні теоретичних засад формування метакогніцій у студентів у процесі навчання та перспектив впровадження авторських програм метакогнітивного навчання у вітчизняних вищих навчальних закладах.

Виклад основного матеріалу. Дослідження метакогнітивних процесів у науці пов'язують 3 науковою школою Дж. Флейвелла, який і став засновником сучасного метакогнітивізму, а його учні на прикладному рівні довели визначну роль метакогнітивних процесів у навчальній, професійній діяльностях, а також інтелектуальному розвитку людини в цілому.

Як зауважував Дж. Флейвелл (Дж. Флейвелл, 2012), метапізнання є видом інтелектуальної активності вищого порядку, що включає до себе функцію контролю над пізнавальними процесами, воно забезпечує успішність розумової діяльності суб’єкта в ситуації невдачі пізнання, дає змогу самостійно виправити ситуацію та вирішити складне завдання особистого чи професійного характеру. Метапізнання, на думку вченого, є складним явищем та містить:

- когнітивні цілі та завдання - усвідомлені цілі реальної ситуації, що відповідають ії реальним 
обставинам;

- метакогнітивне знання - знання суб'єкта про власні розумові можливості, механізми регулювання власною мисленнєвої діяльністю;

- когнітивні дії та стратегії - система способів досягнення цілей у ситуації, що вимагає значних когнітивних зусиль;

- метакогнітивний досвід - певні спогади людини про використані у різних ситуаціях метакогнітивні уміння; це свідоме дослідження ментального досвіду, що супроводжує вдалі та невдалі ситуації у навчанні й іншій розумовій діяльності.

Базовим механізмом, що актуалізує метапізнання, згідно із твердженнями самого Дж. Флейвелла та його послідовників (А. Браун, Б. Величковський, Дж. Уілсон та ін.), є рефлексія - як процес критичного осмислення власної діяльності та миследіяльності, вміння виділяти, аналізувати та співвідносити власні предметні та розумові дії; процес обгрунтування необхідності внесення коректив у перебіг власної розумової діяльності [4: 151-162].

Характеризуючи метакогнітивні процеси, А. В. Карпов (А. В. Карпов, 2004) також наголошує на їх вищому порядку порівняно з первинними когнітивними процесами (це синтетичні, регулятивні процеси другого порядку, що є інтегральними метапроцесами); їх психічному характері за механізмами реалізації; суб'єктивності, ідеальності, цілеспрямованості, предметності; специфічному операційному складі; спрямованості на забезпечення найбільш загальних адаптивних функцій; двоєдиності за своєю природою (вони є когнітивними за своїми механізмами та регулятивними за спрямованістю, функціональному призначенню); можливості забезпечення становлення "самості" суб'єкта, суб'єктності не тільки у ставленні до зовнішнього світу, але й до внутрішнього - до своєї власної психіки, ії змісту [5: 137-259].

У зазначеному контексті важливим $є$ висновок про те, що когнітивні стратегії $є$ підгрунтям для досягнення пізнавальної мети, а метакогнітивні - для перевірки (певного контролю) щодо її досягнення.

Науковцями досліджуються й особливості метапізнавальної діяльності студентів, іiі специфіка та механізми цілеспрямованого розвитку. Так, у працях К. Амеса, Д. Бренсфорда, П. Вінна, Дж. Девідсона, А. Худвіна та ін. узагальнено характеристики розумової діяльності академічно неуспішних студентів різних спеціальностей порівняно з успішними, які висвітлюють їх особливості метапізнання, а саме:

- мають низький рівень внутрішньої мотивації розвитку власної розумової діяльності, 3 опором ставляться до виконання завдань на актуалізацію загальних мисленнєвих процесів;

- мають труднощі при визначенні мети діяльності взагалі та власної розумової діяльності, не можуть визначити ії завдання та очікувані результати;

- при засвоєнні навчального матеріалу опрацьовують його швидко, не зупиняючись на проблемних аспектах; дають оцінку легкості навчальному матеріалу, не можуть визначити часові межі для його опанування; не можуть визначити рівень власної впевненості у результатах вивчення, усвідомити успіхи власної розумової діяльності; не усвідомлюють, коли розуміють матеріал, а коли ні; що потрібно зробити для подолання труднощів; не можуть автоматично пов'язати нову інформацію з тією, яка вже була засвоєна;

- не мають власних навчальних стратегій, не можуть розрізнити умови, в яких потрібно застосувати те чи інше вміння; вони не можуть ставити запитання на розуміння та рефлексію; не використовують методи схематизації навчального матеріалу, не можуть схематизувати процес власної розумової діяльності;

- не можуть правильно ідентифікувати проблему, що призводить до втрати часу та зайвих зусиль.

Як засіб подолання визначених проблем, Т. О. Нельсон та Л. Наренс (T. O. Nelson, L. Narens, 1990) пропонують ряд базових прийомів поетапної актуалізації процесів метапізнання студентів: 1) оцінка ступеня легкості вивчення матеріалу, що мимовільно спонукає студента звернути увагу на матеріал, який йому необхідно вивчити; осмислення того, що вже відомо із поточної теми; аналіз своїх можливостей та здібностей у межах актуального матеріалу, врахування умов реалізації процесу навчання; 2) оцінка якості вивчення як засіб визначення можливостей для внесення коректив у процес учіння; 3) оцінка відчуття засвоєння - аналіз ступеня розуміння навчального матеріалу; 4) оцінка ступеня впевненості - визначення правильності використання метакогнітивних умінь та стратегій при вирішенні певного завдання [6: 125173].

Ефективним педагогічним засобом формування метакогніцій у студентів, на думку Г. Шро та Д. Мошмана (G.Schraw, D. Moshman, 1995), є проходження тестування після запам'ятовування навчального матеріалу, навіть коли продуктивність відтворення під час тесту невисока і не має зворотного зв'язку. Ефект покращення відтворення інформації за допомогою використання тестування в процесі запам'ятовування інформації називається "ефектом тестування". Він посилюється в ситуації рефлексивного аналізу результатів тесту, визначення шляхів подолання невірних відповідей [7: 351-371].

Програма цілеспрямованого розвитку метакогнітивних стратегій М. А. Діркеса (M. A. Dirkes, 1985), впровадження якої у ВНЗ має значні позитивні результати, включає такі формувальні інструменти, як:

1) чіткий розподіл відомого та невідомого у проблемних ситуаціях (у процесі розв'язання проблемної ситуації рекомендовано чітко, передусім у письмовій формі, розділяти всю інформацію на відому та 
невідому, постійно доповнюючи та уточнюючи весь ії обсяг);

2) вербалізація процесу мислення (робота над умінням говорити про мислення, вербально визначати його етапи, труднощі, мисленнсві стратегії та результати, завдяки демонстрації мислення вголос, мислення про мислення та обговоренню (парному, груповому, колективному) особливостей мислення при вирішенні різного роду професійних завдань);

3) ведення щоденника мислення, в якому записуються роздуми про власне мислення, його труднощі, що виникають у процесі вирішення навчально-професійних завдань;

4) планування та саморегуляція мислення (планування навчальних заходів - їх частоти, тривалості, обсягу матеріалу для своєчасного та успішного вирішення поставлених завдань);

5) формулювання стратегій мислення (вирішення завдань зі спостереженням за думками, почуттями, процесами, які супроводжують рішення; узагальнення, класифікацію отриманої інформації та первинне формулювання стратегій; прикінцеве формулювання та операціоналізацію способів мислення);

6) самооцінка ефективності мислення за різними критеріями [8: 96-100].

3 урахуванням проведеного аналізу наукових праць, базовими механізмами формування метакогнітивних знань та вмінь студентів у зарубіжній вищій школі, визначено: 1) вербалізацію власного мисленнєвого потенціалу у ході вирішення навчально-професійних завдань; 2) рефлексивний аналіз власної розумової діяльності з ідентифікацією проблеми, формулюванням іiї мети, завдань шляхів вирішення та оцінкою отриманих результатів; 3) схематизацію (структурування) власної розумової діяльності; 4) відпрацювання метакогнітивних стратегій у груповій роботі; 5) використання методів рефлексивних запитань на різних етапах розумової діяльності; 6) застосування методу метакогнітивних пауз у ході засвоєння навчального матеріалу; 7) самодіагностика індивідуальних метакогнітивних стратегій та визначення найбільш успішних в аспекті власного навчального досвіду.

Зазначені механізми актуалізуються й у процесі професійної підготовки майбутніх фахівців у вітчизняних вищих навчальних закладах шляхом застосування відповідних форм (практикум, тренінг, спецкурс) та методів індивідуальної, групової і колективної роботи.

Так, у процесі професійної підготовки майбутніх фахівців різних напрямів підготовки успішно впроваджуються окремі тренінгові програми 3 формування метакогнітивних умінь (цілепокладання, прийняття рішень, планування власної розумової діяльності, тайм-менеджменту, brain-фітнесу та ін.), оргдіяльнісні ігри, метакогнітивні дискусії тощо.

Педагогічною інтерпретацією метакогнітивних процесів на рівні методичної складової навчального процесу є використання таких механізмів засвоєння інформації, як техніка повторювання (утримування інформації у короткостроковій пам'яті, що передбачає механічне, так зване поведінкове, іії повторення; результат - затримання інформації на короткий час); техніка кодування (створення зв'язків із даними, які вже накопичено мозком; результат - довгострокове запам'ятовування інформації); техніка глибокого аналізу, перетворення інформації (докладний аналіз матеріалу, що пов'язує нові повідомлення з тими, які $є$ у пам'яті, надає їм глибокого змісту; результат - довге утримування у пам'яті та ін. [9: 21-22].

Проте все це $є$ тільки початком великої системної роботи, що відповідає найгострішим викликам сьогодення в контексті забезпечення новітніх вимог суспільства до фахівців.

Висновки. Отже, такий підхід до розгляду проблеми удосконалення пізнавальної діяльності студентів вишів варто розглядати як один із шляхів підвищення якості освітніх послуг, формування конкурентоспроможного людського капіталу на сучасному ринку праці. Разом 3 тим, здійснений аналіз наукового розуміння сутності метакогніцій, ролі метакогнітивних процесів в навчально-професійній, академічній діяльності студентів, а також механізмів їх цілеспрямованого розвитку, є певним підгрунтям для актуалізації та активізації розробки авторських програм метакогнітивного навчання та їх упровадження у вітчизняних ВН3.

\section{СПИСОК ВИКОРИСТАНИХ ДЖЕРЕЛ ТА ЛІТЕРАТУРИ}

1. Сидорчук Н. Г. Система професійно-педагогічної підготовки студентів університетів у контексті єдиного європейського освітнього простору : дис. ... докт. пед. наук : 13.00 .04 / Сидорчук Нінель Герандівна. Житомир, 2014. - 515 с.

2. Випускники українських ВНЗ очима роботодавців [Електронний ресурс]// C. Yourcompass.org. - Режим доступу : http://www.yourcompass.org/docs/Employees\%20on\%20University_Graduates.pdf. - 15. 09. 2017 p. Загол. $з$ екрану.

3. Флейвелл Дж. Генетическая психология Ж. Пиаже / Дж. Флейвелл. - М. : "Просвещение". - 598 с.

4. Флейвелл Дж. Когнитивное развитие и метапознание / Дж. Флейвелл // Горизонты когнитивной психологи : [хрестоматия] / под ред. В. Ф. Спиридонова и М. В. Фаликман. - М. : РГГУ, 2012. - 437 с.

5. Карпов А. В. Психология рефлексивных механизмов деятельности / А. В. Карпов. - М. : Изд-во "Институт психологии РАН", 2004. - 424 с.

6. Nelson T. O. Metamemory : A Theoretical Framework and New Findings / T. O. Nelson, L. Narens // The Psychology of Learning and Motivation, 1990. - Vol. 26. - Pp. 125-173.

7. Schraw G. Metacognitive Theories / G. Schraw, D. Moshman// Educational Psychology Review. - 1995. - № 7 P. 351-371. 
8. Dirkes M. A. Metacognition : Students in Charge of Their Thinking / Dirkes M. A. // Roeper Review. - 1985. - № 8 (2). - P. 96-100.

9. Сидорчук Н. Г. Інструктивно-методичні матеріали до курсу педагогіка. Загальні основи. Ч. I (спеціальність практична психологія) : [метод. посіб.] (4 вид., перероблене та доповнене) / Н. Г. Сидорчук. - Житомир : Видво ЖДУ ім. І. Франка, 2013. - 144 с.

\section{REFERENCES (TRANSLATED \& TRANSLITERATED)}

1. Sydorchuk N. H. Systema profesiino-pedahohichnoi pidhotovky studentiv universytetiv u konteksti yedynoho yevropeys'koho osvitn'oho prostoru [The System of Vocational and Pedagogical Preparation of University Students in the Context of a Single European Educational Space] : dys. ... dokt. ped. nauk: 13.00.04 / Sydorchuk Ninel' Herandivna. - Zhytomyr, 2014. - $515 \mathrm{~s}$.

2. Vypusknyky ukrains'kykh VNZ ochyma robotodavtsiv [Graduates of Ukrainian Universities by the Eyes of Employers] $\begin{array}{lllllll}\text { [Elektronnyi } & \text { resurs] } & / / & \text { S. Yourcompass.org } & - & \text { Rezhym }\end{array}$ http://www.yourcompass.org/docs/Employees\%20on\%20University_Graduates.pdf. - 15.09.2017 r. - Zahol. z ekranu.

3. Fleivell Dzh. Geneticheskaia psihologiia Zh. Piazhe [Genetic Psychology of J. Piaget] / Dzh. Fleivell. - M. : "Prosveschenie". - $598 \mathrm{~s}$.

4. Fleivell Dzh. Kognitivnoe razvitie i metapoznanie [Cognitive Development and Metacognition] / Fleyvell Dzh. // Gorizontyi kognitivnoi psihologii : [hrestomatiia] / pod red. V. F. Spiridonova i M. V. Falikman. - M. : RGGU, 2012. $437 \mathrm{~s}$.

5. Karpov A. V. Psihologiia refleksivnykh mehanizmov deyatel'nosti [Psychology of Reflexive Mechanisms of Activity] / A. V. Karpov. - M. : Izd-vo "Institut psikhologii RAN", 2004. - 424 s.

6. Nelson T. O. Metamemory : A Theoretical Framework and New Findings / T. O. Nelson, L. Narens // The Psychology of Learning and Motivation, 1990. - Vol. 26. - Pp. 125-173.

7. Schraw G. Metacognitive Theories / G. Schraw, D. Moshman. // Educational Psychology Review. - 1995. - № 7 P. 351-371.

8. Dirkes M. A. Metacognition : Students in Charge of Their Thinking / Dirkes M. A. // Roeper Review. - 1985. № 8 (2). - P. 96-100.

9. Sydorchuk N. H. Instruktyvno-metodychni materialy do kursu pedahohika. Zahal'ni osnovy. Ch. I (spetsial'nist' praktychna psykholohiia) [Tutorial-Methodical Materials for the Course of Pedagogy. General Basics. Ch.I (Specialty Practical Psychology)] : [metod. posib.] (4 vyd., pereroblene ta dopovnene) / N. H. Sydorchuk. - Zhytomyr : Vyd-vo ZhDU im. I. Franka, 2013. - 144 s.

\section{Сидорчук Н. Г. Формирование метакогниций будущцх специалистов в высией иколе: опыт и перспективы внедрения в учебный процесс отечественных учебных заведений.}

В статье рассматривается проблема усовершенствования подготовки будущих специалистов с учетом когнитивно-стилевых особенностей их учебной познавательной деятельности. Ключевым психологопедагогическим механизмом повышения эффективности овладения профессиональными знаниями названы метакогнитивные процессы. Обобщены теоретические выводы содержательных характеристик метакогниций. Доказана необходимость учета механизмов действия метакогнитивных процессов в профессиональной подготовке будущих специалистов. Определены перспективы разработки и внедрения авторских программ метакогнитивного обучения в отечественных вузах.

Ключевые слова: высшая школа, профессиональная подготовка будущих спещииалистов, когнитивные прочессы, метакогнитивные процессы.

\section{Sydorchuk N. G. Formation of Metacognition of Future Specialists in Higher Education: Experience and Perspectives of Introduction into the Educational Process of Domestic Educational Institutions.}

The research deals with the problem of improving the training of future specialists, taking into account cognitivestylistic peculiarities of educational cognitive activity. The material of the research includes a theoretical analysis of the content characteristics of metacognition as a key psychological and pedagogical mechanism for increasing

the efficiency of mastering professional knowledge. It is concluded that cognitive strategies are the basis for achieving the cognitive purpose, and metacognitive - to check (certain control) in achieving it. The obtained results prove the necessity of taking into account the mechanisms of action of metacognitive processes in the professional training of future specialists. The peculiarities of the purpose of cognitive activity of students, the basic mechanisms

of formation of metacognitive knowledge and skills in foreign and domestic high schools are analyzed. The prospects for the development and implementation of author programs of metacognitive training in the Ukrainian higher educational institutions are determined. It was also concluded that the use of metacognitive strategies in the course of professional training of future specialists provides for the improvement of the quality of educational services, the formation of competitive human capital in the modern labour market.

Key words: higher school, professional training of future specialists, cognitive processes, metacognitive processes. 